\title{
Peta Literasi Media Pemilih Pemula di Surabaya
}

\section{Media Literacy Map for Beginner Voters in Surabaya}

\author{
Agatha Winda Setyarinata \& Theresia Intan Putri Hartiana* \\ Universitas Katolik WIdya Mandala Surabaya \\ J1. Dinoyo no. 42-44 Surabaya 60112 \\ *e-mail: theresiaintan@ukwms.ac.id
}

Submitted: 10-05-2021, Revised: 11-06-2021, Accepted: 21-06-2021, Published: 19-07-2021

Doi: : https://doi.org/10.33508/jk.v10i1.3156

\begin{abstract}
This research aims to map the level of media literacy among first voters in Surabaya. Misinformation is a threat to society in this digital era. In tihis conditions, it is important. o take the information we need and digest it, especially political news during elections. 300 first-time voters were participated in this research. They are range 17 to 20 years old. The research method used a survey. Measurement of media literacy refers to the European Commission. The result shows that majority of first-time voters are in technical skill level.. The first-time voters are also literate to content about election that spread all over the internet (critical abilities). They are able to distinguish the election news which contain hoax. Although they are savvy in technical skills level and in critical abilities level, they do not adopt the communicative abilities. This means they do not participate in creating written content and visual/audio-visual content about the election. They tend to not repost and add caption to a content about election.
\end{abstract}

Keywords: media literacy, first-time voters, election 2019, hoax, technical skills

\begin{abstract}
ABSTRAK
Penelitian ini bertujuan untuk memetakan tingkat literasi pemilih pemula di Surabaya. Misinformasi menjadi ancaman bagi masyarakat di era digital ini. Di kondisi yang seperti ini, sangat penting sekali, mengambil informasi yang kita perlukan, dan mencernanya, terutama berita politik pada saat Pemilu. Penelitian dilakukan dengan mengambil sampel acak sebanyak 300 orang di kalangan pemilih pemula usia 17-21 tahun. Metode penelitian menggunakan survey. Pengukuran media literacy mengacu pada European Commission. Hasil menunjukan bahwa pemilih pemula berada pada level technical skill. Pemilih pemula juga melek dengan konteks konten-konten tentang pemilu yang tersebar di internet (critical abilities). Pemilih pemula dapat menyadari bahwa ada berita pemilu yang bersifat hoax/berita palsu. Mereka dapat melakukan verifikasi ketika mereka menerima berita palsu hanya mempercayai sumber berita yang kredibel. Kendati piawai dalam technical skills dan memiliki critical abilities, pemilih pemula tidak berada pada kemampuan komunikatif. Ini berarti mereka cenderung tidak terlibat dalam pembuatan konten tentang pemilu, baik dalam bentuk artikel maupun bentuk konten visual/audio visual. Mereka juga cenderung tidak menduplikasi tautan (repost) konten pemilu dengan menambahkan tajuk.
\end{abstract}

Kata kunci: literasi media, pemilih pemula, pemilu 2019, hoax, technical skills 


\section{Latar Belakang}

Kecanggihan media komunikasi bersama dengan internet membuka kesempatan bagi manusia untuk mendapatkan informasi, termasuk informasi tentang pemilu. Dengan website KPU yang bisa diakses secara luar, distribusi berita-berita pemilu melalui situs berita online, informasi pemilu bisa dengan mudah diakses. Namun, Kecepatan dan kemudahan mendapatkan informasi ini bukan berarti tanpa ancaman. Misinformasi menjadi ancaman bagi masyarakat di era digital ini. Ancaman misinformasi memang tidak bisa dihentikan dengan sekejap; perlu upaya literasi yang konsisten untuk dilakukan (Susman-peña et al., 2020)

Ancaman misinformasi ini semakin nyata ketika jurnalis memiliki cara kerja baru dalam era internet. Jurnalis masa kini memiliki tantangan terkait profesionalitas dengan kebutuhan ekonomi dalam memproduksi berita (Hamna, 2017) Ketika banyak audiens yang sudah berpaling dari media arus utama ke internet, maka media harus menghadapi pasar baru. Hal ini berarti jurnalis harus memproduksi berita agar mendapat banyak pembaca yang nantinya bisa dijual ke pengiklan. Menghadapi tantangan yang seperti ini, jurnalis tidak jarang menulis judul yang provokatif memang dapat mendulang klik (clickbait), namun ini tidak selamanya hal yang etis untuk dilakukan.

Produksi konten hoax sepenuhnya merupakan kemampuan pengguna baik menciptakan, merubah, memodifikasi, hingga menyebarkan melalui media sosial. Hal ini ikut diperparah dengan kondisi masyarakat Indonesia yang dengan mudah percaya begitu saja dengan berita yang beredar. Ini juga dikarenakan hoax diproduksi seolah-olah dari situs berita ternama seperti kompas.com dan situs luar negeri, sehingga ikut menimbulkanrasa percaya masyarakat terhadap berita tersebut(Juditha, 2018)

Ketika praktik yang seperti ini menjadi sebuah gejala umum, maka upaya untuk memverifikasi informasi menjadi pekerjaan yang tidak mudah bagi orang awam. Terlebih ketika produksi informasi tidak berhenti dan menjadi sebuah badai informasi. Di kondisi yang seperti ini, sangat penting sekali untuk menepi, mengambil informasi yang kita perlukan, dan mencernanya. Kemampuan literasi membantu manusia untuk benar-benar melihat dan memahami informasi yang mereka terima (Huvila, 2012)

Allcott, H., \& Gentzkow, dalam penelitiannya terkait Social Media an Fake news in the 2016 Election mengemukan, berita hoaks dan berbagai ujaran kebencian dalam kegiatan pemilu akan mampu mempengaruhi seseorang dalam menentukan pilihannya. (Tacchini et al., 2017) Sejalan dengan itu pula mengungkapkan hoaks dinilai dapat menjadi ancaman bagi generasi muda untuk dapat memilih secara rasional dan cerdas. Terutama karena pemilih pemula belum memiliki informasi menyeluruh, sehingga dengan mudah mereka berprasangka dan mungkin juga ketidakpercayaan terhadap calon yang diberitakan bohong.(Astrika \& Yuwanto, 2019)

Riset Masyarakat Telematika (Mastel) menyebutkan pada tahun 2016 sebaran berita hoax lebih banyak didominasi oleh berita hoax politik. Dalam riset Mastel tersebut ditemukan

fakta bahwa 91,8 persen responden mengaku paling sering menerima konten hoax tentang sosial politik, seperti pemilihan kepala daerah dan pemerintahan. Sejalan dengan itu pula mengungkapkan kecenderungan hoax pada Pemilu Presideo di Media Daring dan Media Sosial digurnakan untuk 
mengarahkan pada agenda setting dan kepanikan. publik dengan prosentase sebesaar $45 \%$ dan $40 \%$, sedangkan sisanya $5 \%$ merupakan berita hoax yang mengarah pada opini public pada salah satu kandidat politil. (Sosiawan \& Wibowo, 2020)

Kemampuan literasi menjadi penting bagi pemilih pemula dalam masa pemilu, misalnya untuk mencari dan memahami informasi tentang pemilu. Pemilih pemula dapat memanfaatkan keberadaan media sosial dan berbagai situs lain sebagai sumber informasi terkait Pemilu 2019, misalnya melalui platform seperti Twitter, Facebook, Instagram, website KPU, dan lain sebagainya. Kendati ada kemudahan, informasi yang tersebar dalam media sosial sangat beragam dan berjumlah banyak. Tidak semua informasi yang didapatkan melalui sosial media dapat membantu kebutuhan pemilih pemula. Selain itu, pemilih pemula juga dihadapkan pada ancaman hoax.

.Lebih dari $80 \%$ remaja di Surabaya menggunakan media sosial untuk melihat berita, itu berarti besar kemungkinan bahwa remaja Surabaya menemukan berita Hoaks di media sosial(Novia \& Mustika, 2019)

Hasil penelitian yang dilakukan oleh Novia mengungkapkan untuk pemilih muda di Surabaya sendiri didapatkan data bahwa pengetahuan moral (moral knowing) Moral feeling (perasaan moral) dan belum mencapai tingkat komponen Moral action (tindakan), atau dengan kata lain bahwa pemilih muda Surabaya memiliki pengetahuan yang kritis terhadap berita hoax di media sosial tentang pemilihan presiden 2019. Akan tetapi pemilih muda Surabaya hanya memiliki tindakan yang netral terhadap berita hoax di media sosial tentang pemilihan presiden 2019(Novia \& Mustika, 2019)
Sehingga dalam penelitian ini, akan dapat mendekripsikan sejauh mana tingkat literasi pemilih pemula. Penanganan hoax berkaitan dengan proses kognitif yang kompleks (John,Cook;Lewandowsky, 2005) Agar berhasil memberikan pengetahuan, komunikator perlu memahami bagaimana orang memproses informasi, bagaimana mereka mengubah pengetahuan mereka yang ada dan bagaimana pandangan dunia mempengaruhi kemampuan mereka untuk berpikir secara rasional(Paskarina \& Rina;Nuraeni, 2017)

Center for Media Literacy merumuskan literasi media sebagai "kemampuan berkomunikasi secara kompeten melalui semua media-baik elektronik maupun cetak"(Iriantara., 2009). Center for Media Literacy (Centre for Media Literacy, 2008) menyebutkan bahwa literasi media mencakup beberapa kemampuan, yaitu: (a) kemampuan mengkritik media, (b) kemampuan memproduksi media, (c) kemampuan mengajarkan tentang media, (d) kemampuan mengeksplorasi sistem pembuatan media, (e) kemampuan mengeksplorasi berbagai posisi, (f) kemampuan berpikir kritis atas isi media.

Sementara itu, European Comission mengungkapkan literasi media sebagai "[...] the ability to access, analyse and evaluate the power of images, sounds and messages which we are now being confronted with on a daily basis and are an important part of our contemporary culture, as well as to communicate competently in media available on a personal basis. Media literacy relates to all media, including television and film, radio and recorded music, print media, the internet and other new digital communication technologies".(Celot \& Pérez Tornero, 2009)

Dari beberapa definisi diatas, oleh Art Silverblatt dan Stanley J. Baran pernah menggagas 7 (tujuh) elemen utama literasi 
media. Silverblat mengusulkan 5 elemen literasi media. Menurutnya, elemen pertama berbicara tentang kesadaran atas dampak media. Elemen kedua adalah sebuah pemahaman tentang proses meida massa. Ketiga adalaha strategi-strategi untuk menganalisis dan mendiskusikan pesan media. Keempat adalah sebuah pemahaman tentang konten media sebagai sebuah teks yang menyajikan ide tentang budaya kita dan kehidupan kita. Terakhir, eleman kelima adalah kemampuan untuk menikmati, memahami, dan mengapresiasi konten media.

Baran ("Mass Communication," 1994) menambahkan 2 elemen terhadap 5 elemen yang sudah digagas Silverblatt. Elemen pertama adalah pemahaman tentang kewajiban etis dan moral di kalangan pelaku media. Elemen kedua adalah pengembangan skil produksi yang efektif dan pantas. Tambahan dua elemen ini menjadi sebuah menjadi sebuah masukan yang masih relevan di era internet ini. Terutama karena di era ini, audiens tidak hanya sebatas menikmati konten media, namun juga bisa turut memproduksi konte. . Hal ini juga kongruen dengan gagasan Potter yang menyebutkan tahap sistesis dan abstraksi

Dari kemampuan literasi media tersebut diharapkan akan membawa dampak perubahan dalam kemampuan audiens untuk

- Analysis: breaking down a message into meaningful elements

- Evaluation: judging the value of an elements; the judgement is made by comparing the element of some criterion

- Grouping: determining which elements are alike in some way; determining which elements are different in some way

- Induction: inferring a pattern across a small set of elements, then generalizing the pattern to all elements in the set
- Deduction: using general principles to explain particulars

- Synthesis: assembling elements into a new structure

- Abstracting: creating a brief, clear, and accurate description capturing the essence of message in a smaller number of words than the message itself (Potter, n.d.)

Menurut European Commission kemampuan literasi media dapat diukur dengan menggunakan Individual Competence Framework dalam Final Report Study on Assessment Criteria for Media Literacy Levels tahun 2009 yang dilaksanakan oleh European Commission. Sebelumnya framework tersebut digunakan untuk mengukur tingkat literasi media masyarakat di negara-negara Uni Eropa.

Gambar 1. Tingkatan Media Literacy

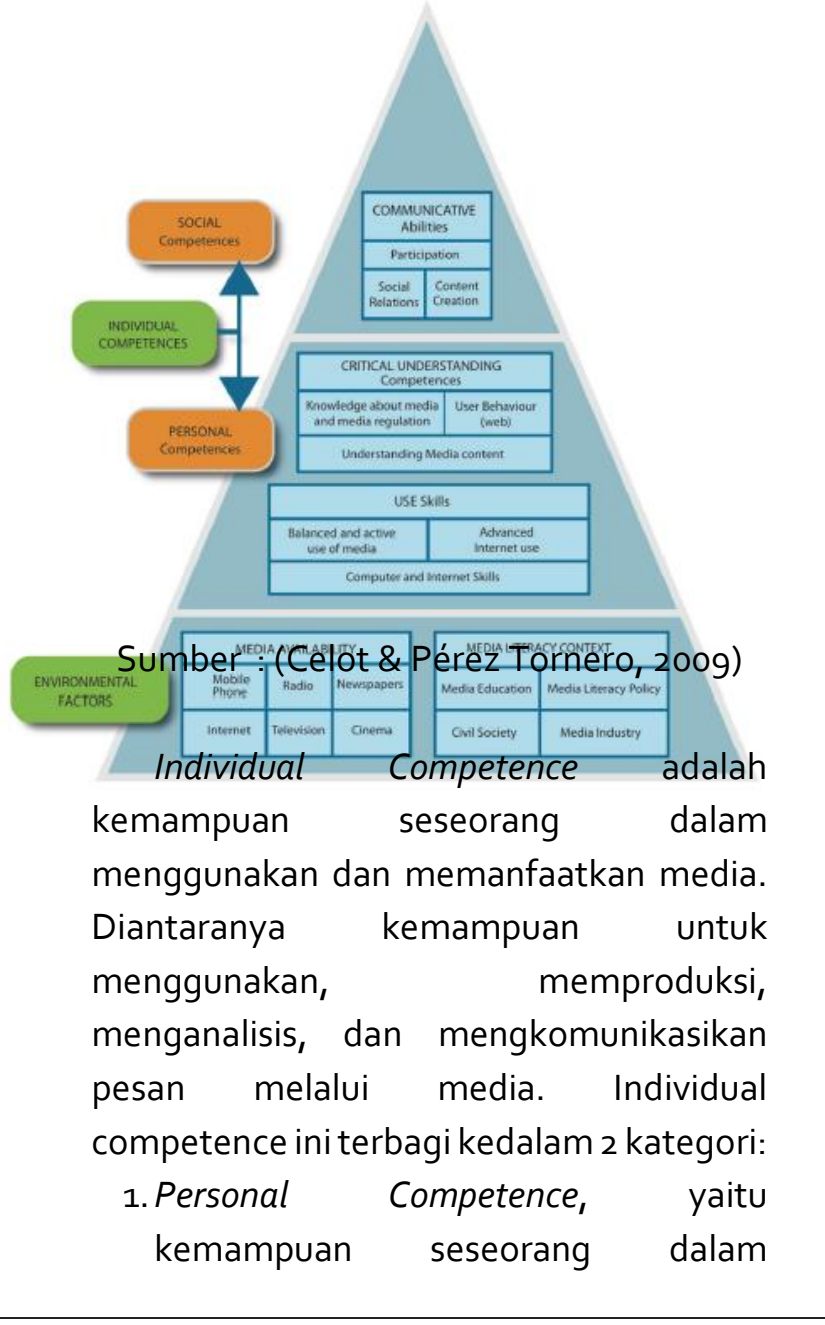

Jurnal KOMUNIKATIF Vol. 10 No. 1 Juli 2021 
menggunakan media dan menganalisis konten-konten media.

2.Social Competence, yaitu kemampuan seseorang dalam berkomunikasi dan membangun relasi sosial lewat media serta mampu memproduksi konten media.

Personal competence terdiri dari dua kriteria:

1. Technical skills, yaitu kemampuan teknik dalam menggunakan media. Artinya, seseorang mampu mengoperasikan media dan memahami semua jenis instruksi yang ada didalamnya. Kemampuan untuk mengakses dan mengoperasikan media. Technical skills ini mencakup beberapa kriteria, yaitu:

a. Kemampuan menggunakan komputer dan internet (computer and internet skills).

b. Kemampuan menggunakan media secara aktif (balanced and active use of media).

c. Kemampuan menggunakan internet yang tinggi (advanced internet use).

2. Critical Understanding, yaitu kemampuan kognitif dalam menggunakan media seperti kemampuan memahami, menganalisis, dan mengevaluasi konten media.

Kriteria critical understanding ini antara lain adalah:

a. Kemampuan memahami konten dan fungsi media (understanding media content and its functioning).

b. Memiliki pengetahuan tentang media dan regulasi media (knowledge about media and media regulation).

c. Perilaku netter dalam menggunakan media (user behavior).
Social competence terdiri dari Communicative Abilities, yaitu kemampuan komunikasi dan partisipasi melalui media. Communicative abilities ini mencakup kemampuan untuk membangun relasi sosial serta berpatisipasi dalam lingkungan masyarakat melalui media. Selain itu, communicative abilities ini juga mencakup kemampuan dalam membuat dan memproduksi konten media.

a. Kemampuan untuk bersosialisasi dan berpartisipasi melalui media serta memproduksi konten media. Communicative abilities ini mencakup beberapa kriteria, yaitu: Kemampuan berkomunikasi dan membangun relasi sosial melalui media (social relations).

b. Kemampuan berpartisipasi dengan masyarakat melalui media (citizen participation).

c. Kemampuan untuk memproduksi dan mengkreasikan konten media (content creation).

Salah satu cara yang bisa dilakukan untuk menghentikan hoaks adalah dengan literasi media.(Hidayat, Dadang Rahmat ; Basith, 2019)

Jalur pemberdayaan para pengguna media sosial melalui literasi digital dan etika adalah keharusan untuk menciptakan suatu tatanan komunikasi di media sosial yang jauh lebih positif.Literasi akan mampu memberiikan sikap kritis kepada para pengguna media sosial(Rianto, 2019)

\section{Metode}

Metode yang kami gunakan dalam penelitian ini adalah metode survey tipe penelitian deskriptif dengan teknik pengumpulan data menggunakan kuesioner kepada para pemilih pemula. populasi pemilih pemula di Surabaya berjumlah 35.140 orang. Cara pengambilan sampel dengan teknik sampel acak/random 
sampling/probability sampling. Cara pengambilan sampel ini memberikan kesempatan yang sama untuk diambil kepada setiap elemen populasi. Sampel adalah "sebagian dari keseluruhan objek atau fenomena yang akan diamati" (Kriyantono, 2006). Secara minimum tolak ukuran untuk penelitian deskriptif yaitu sekurang-kurangnya 100 sampel atau $10 \%$ dari populasi (Ruslan, 2003). Sehingga sample keseluruhan dalam penelitian ini sebanyak 300 pemilih pemula.

Karena harapannya dalam kontek literasi, netizen atau pengguna media sosial khusunya dalam menanngapi isu hoaks dalam pemilu yang memiliki kemampuan literasi media cukup tinggi, tak hanya sadar pada etika berkomunikasi saja tetapi juga memiliki keterampilan kosntruktif dalam menerima, memproduksi dan membagikan muatan informasi(berita)(Juliswara, 2017).

Teknik analisis data dilakukan dengan cara

1. Uji Validitas

Validitas dimaksudkan untuk menyatakan sejauh mana instrumen (misalnya kuesioner) akan mengukur apa yang ingin

2. Uji Reliabilitas

Menganalisis data tentang literasi teknik analisis data yang digunakan adalah

1. Distribusi Frekuensi

Deskriptif frekuensi bertujuan untuk menampilkan dan mendeksripsikan atau menggambarkan data

Pengukurannya menggunakan skala Likert dimana responden menyatakan tingkat setuju atau tidak setuju berjenjang 5 (lima) untuk mengetahui keefektifitasan komunikasinya. Kategori jawaban yang disediakan, yaitu "Selalu (S)", "Sering $(\mathrm{SR})$ ", "Kadang-kadang (K)", "Jarang (J)", "Tidak Pernah (TP)", dengan memberikan skor

$\begin{array}{lr}\text { Selalu (S) } & \text { skor } 5 \\ \text { Sering (SR) } & \text { skor 4 } \\ \text { Kadang-kadang (K) } & \text { skor 3 } \\ \text { Jarang (J) } & \text { skor 2 } \\ \text { Tidak Pernah (TP) } & \text { skor 1 }\end{array}$

Untuk menentukan literasi, maka dilakukan penghitungan rata-rata semua pertanyaan tentang literasi media dan digunakan interval kelas yang dicari dengan rumus sebagai berikut :

Nilai Tertinggi-Nilai Terendah $\quad$ 5-1 $=1,33$ Jumlah Kelas 3

Penentuan tingkat media literasi berdasarkan penghitungan rumus diatas, maka ditentukan bobot masing-masing komponen dengan kategori sebagai berikut :

- Untuk nilai 1,00 - 2,33 dikatakan literasi medianya berada pada tingkat basic.

- Untuk nilai 2,34-3,67 dikatakan literasi medianya berada pada tingkat medium.

- Untuk nilai 3,68 - 5,00 dikatakan literasi medianya berada pada tingkat advanced.

\section{Pembahasan}

Responden yang berpartisipasi dalam penelitian ini terdiri dari laki-laki (41.7\%) dan perempuan (58.3\%). Responden berasal dari rentang usia 17 hingga 23 tahun.

Mayoritas tingkat pendidikan responden adalah strata 1 (67.\%). Sedangkan lainnya memiliki tingkat 
pendidikan SMA atau yang sederajat (32.4\%), D3 (0.3.\%).

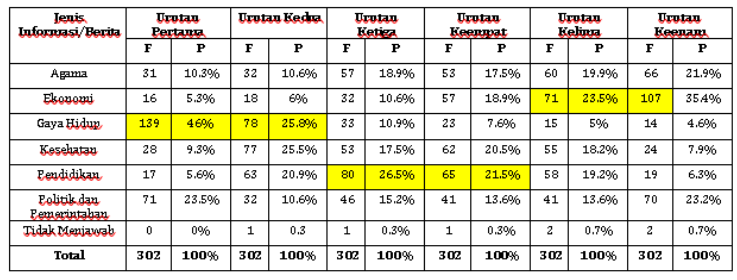

Tabel 1. Topik Berita yang diakses

\section{Sumber : Olahan Data}

Data yang diperoleh dari responden menunjukkan bahwa ada topik-topik berita tertentu yang sering diakses. Sebanyak $46 \%$ responden memilih topik gaya hidup sebagai topik utama yang mereka mencari berita. Topik gaya hidup menjadi topik yang paling banyak dicari oleh responden, terbukti dengan munculnya topik gaya hidup sebagai topik kedua yang paling sering diakses (25.8\%). Dengan demikian, topik gaya hidup secara berturut-turut muncul dalam urutan informasi/berita yang diakses oleh responden.

Menyusul di urutan ketiga (26.5\%) dan urutan keempat (21.5\%) muncul topik pendidikan sebagai topik yang paling sering diakses. Pada urutan kelima (23.5\%) dan keenam (35.4\%), muncul topik ekonomi sebagai topik yang paling sering diakses. Dengan demikian, topik politik dan pemerintahan tidak pernah masuk dalam urutan tertinggi preferensi topik informasi/berita yang diakses oleh responden.

Tabel 2. Media Massa yang diakses

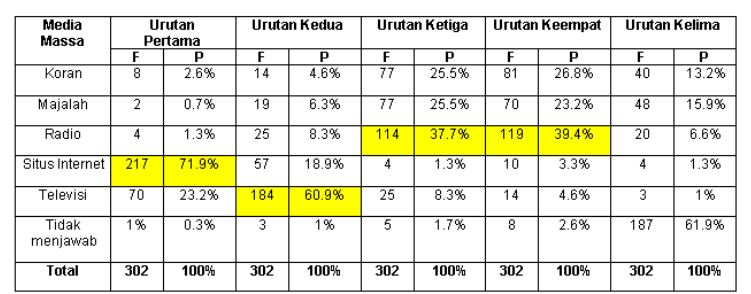

Sumber : Olahan Data

Terkait preferensi kanal media massa, ditemukan bahwa sebanyak $71.9 \%$ responden paling sering mencari informasi lewat media online/internet. Pada urutan kedua, muncul televisi sebagai kanal media massa yang paling sering diakses (60.9\%). Pada urutan ketiga (37.7\%) dan keempat (39.4\%), responden menyebutkan bahwa mereka paling sering mengakses radio

Tabel 3. Jenis Gadget yang digunakan

\begin{tabular}{|c|c|c|c|c|c|c|}
\hline $\begin{array}{c}\text { Jenis } \\
\text { Gadget yang } \\
\text { digunakan }\end{array}$ & \multicolumn{2}{|c|}{$\begin{array}{c}\text { Urutan } \\
\text { Pertama }\end{array}$} & \multicolumn{2}{|c|}{ Urutan Kedua } & \multicolumn{2}{|c|}{ Urutan Ketiga } \\
\cline { 2 - 7 } & $\mathbf{F}$ & $\mathbf{P}$ & $\mathbf{F}$ & $\mathbf{P}$ & $\mathbf{F}$ & $\mathbf{P}$ \\
\hline Desktop/Laptop & 7 & $2.3 \%$ & 195 & $64.6 \%$ & 98 & $32.5 \%$ \\
\hline Handphone & 289 & $95.7 \%$ & 7 & $2.3 \%$ & 5 & $1.7 \%$ \\
\hline Tablet & 5 & $1.7 \%$ & 98 & $32.5 \%$ & 186 & $61.6 \%$ \\
\hline Tidak menjawab & 1 & $0.3 \%$ & 2 & $0.7 \%$ & 13 & $4.3 \%$ \\
\hline Total & $\mathbf{3 0 2}$ & $\mathbf{1 0 0} \%$ & $\mathbf{3 0 2}$ & $\mathbf{1 0 0} \%$ & $\mathbf{3 0 2}$ & $\mathbf{1 0 0} \%$ \\
\hline
\end{tabular}

Sumber : Olahan Data

Hasil yang menunjukan mayoritas responden yang memilih media online/internet sebagai kanal media massa dapat dipahami melalui preferensi gadget responden. Hasil menunjukan bahwa mayoritas responden (95.7\%) menyebutkan bahwa handphone adalah gadget utama yang paling sering diakses. Gadget lain yang paling sering diakses oleh responden setelah handphone adalah komputer desktop/laptop (64.6\%). Sedangkan tablet menjadi urutan terakhir gadget yang paling sering diakses oleh responden (61.6\%). Dari sini dapat dipahami bahwa handphone telah menjadi gadget utama bagi responden.

Selain itu, responden juga lebih sering mengakses media online/internet dibanding kanal media massa lain. Temuan ini kongruen dengan data dari menyebutkan bahwa penduduk Indonesia 
lebih sering mengakses internet lewat handphone. Masih dalam penelitian yang sama, salah satu tujuan mayoritas penduduk indonesia dalam mengakses internet adalah untuk mencari informasi, termasuk berita.

Kegiatan mengakses internet bagi mayoritas penduduk Indonesia juga mengakses internet juga untuk kepentingan sosial media. Hasil temuan menunjukan bahwa $89.4 \%$ responden memilih Instagram sebagai media sosial yang paling sering diakses. Berada pada urutan kedua, Twitter menjadi media sosial yang paling sering diakses oleh responden (56\%). Facebook berada pada urutan terakhir. Ada 55.6\% responden yang yang menyebutkan facebook sebagai media sosial ketiga yang paling sering diakses. Dari data ini dapat dipahami bahwa Instagram merupakan akun media sosial yang paling sering diakses oleh responden.

Tabel 4. Media Sosial yang diakses

\begin{tabular}{|c|c|c|c|c|c|c|c|c|}
\hline \multirow{2}{*}{ Media Massa } & \multicolumn{2}{|c|}{$\begin{array}{l}\text { Urutan } \\
\text { Petrama }\end{array}$} & \multicolumn{2}{|c|}{ Urutan Kedua } & \multicolumn{2}{|c|}{ Urutan Ketiga } & \multicolumn{2}{|c|}{ Urutan Keempat } \\
\hline & $F$ & $\frac{8}{P}$ & $F$ & $P$ & $\mathrm{~F}$ & $P$ & $\mathbf{F}$ & $\mathrm{P}$ \\
\hline Facebook & 26 & $8.6 \%$ & 91 & $30.1 \%$ & 168 & $55.6 \%$ & 10 & $3.3 \%$ \\
\hline Twitter & 3 & $1 \%$ & 169 & $56 \%$ & 105 & $34.8 \%$ & 7 & $2.3 \%$ \\
\hline Instagram & 270 & $89.4 \%$ & 25 & $8.39 \%$ & 5 & $1.7 \%$ & & \\
\hline Line & 1 & $0.3 \%$ & 5 & $1.6 \%$ & 1 & $0.3 \%$ & 12 & $0.6 \%$ \\
\hline Youtube & & & 2 & 0.7 & 1 & $0.3 \%$ & 3 & $1 \%$ \\
\hline Lainoya & & & 3 & 196 & 3 & $1 \%$ & 46 & $15.2 \%$ \\
\hline Snapchat & & & 1 & $0.3 \%$ & 1 & $0.3 \%$ & 4 & $1.3 \%$ \\
\hline $\begin{array}{l}\text { Tidgk } \\
\text { mendiaw }\end{array}$ & 2 & $0.7 \%$ & 5 & $1.7 \%$ & 17 & $5.6 \%$ & 229 & $75.8 \%$ \\
\hline Email & & & 1 & $0.3 \%$ & & & & \\
\hline Pinterest & & & & & 1 & $0.3 \%$ & & \\
\hline Zenly & & & & & & & 1 & $0.3 \%$ \\
\hline Total & 302 & $100 \%$ & 302 & $100 \%$ & 302 & $100 \%$ & 302 & $100 \%$ \\
\hline
\end{tabular}

\begin{tabular}{|l|l|l|}
\hline Ikut/Tidak & Frekuensi & Persentase \\
\hline Ikut Pemilu & 275 & $91.1 \%$ \\
\hline Golput & 25 & $8.3 \%$ \\
\hline $\begin{array}{l}\text { Tidak } \\
\text { menjawab }\end{array}$ & 2 & $0.7 \%$ \\
\hline Total & 302 & $100 \%$ \\
\hline
\end{tabular}

Sumber : Olahan Data

Selain aplikasi media sosial, responden juga diminta untuk mengurutkan aplikasi chatting yang sering mereka akses. Hasil menunjukan bahwa ada $60.6 \%$ responden yang menyebutkan Line sebagai aplikasi chatting utama yang mereka sering akses. Pada urutan kedua, ada sebanyak 59.6\% responden menyebutkan bahwa WhatsApp adalah aplikasi chatting yang sering mereka akses setelah Line. Selain kedua aplikasi tersebut, responden juga mengakses aplikasi (facebook) Messenger. Ada $61.6 \%$ responden yang menyebutkan bahwa (facebook) Messeger adalah aplikasi chatting yang paling sering mereka akses setelah Line dan WhatsApp.

Tabel 5. Aplikasi Chatting yang digunakan

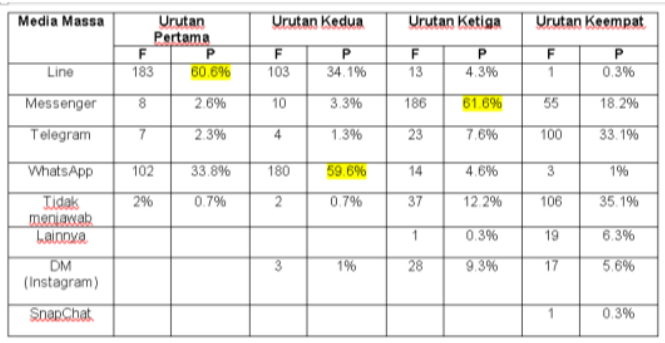

Sumber : Olahan Data

Beralih pada temuan tentang partisipasi responden dalam Pemilu 2019,

Tabel 6. Keikutsertaan dalam Pemilu 2019 Sumber : Olahan Data

Dari data di asta ditemukan bahwa $72.2 \%$ menyebutkan bahwa bahwa Pemilu 2019 merupakan pemilu pertama yang pernah diikuti. Pada Pemilu 2019, ada 24.2\% menyebutkan bahwa Pemilu 2019 merupakan pemilu kedua atau sudah 
pernah mengikuti Pemilu 2014. Sebanyak 3.6\% sisanya

Data keikutsertaan pemilu menunjukan bahwa sebanyak $91.1 \%$ responden tidak golput pada Pemilu 2019. Sedangkan $8.3 \%$ golput dan $0.7 \%$ tidak menjawab. Beberapa alasan yang disebutkan oleh responden adalah belum mendapatkan e-KTP, memiliki KTP luar pulau dan tidak sempat mengurus form $\mathrm{A}_{5}$, sedang berada di luar kota/ luar negeri.

Tabel 7. Alasan tidak mengikuti Pemilu

\begin{tabular}{|l|l|l|}
\hline Alasan & Frekuensi & Persentase \\
\hline $\begin{array}{l}\text { Anak rantau, } \\
\text { tidak } \\
\text { mengurus A5 }\end{array}$ & 1 & $0.3 \%$ \\
\hline $\begin{array}{l}\text { Belum dapat } \\
\text { KTP }\end{array}$ & 2 & $0.7 \%$ \\
\hline $\begin{array}{l}\text { Belum } \\
\text { mengurus di } \\
\text { karena } \\
\text { Jakarta }\end{array}$ & 1 & $0.3 \%$ \\
\hline $\begin{array}{l}\text { Belum punya } \\
\text { E-KTP }\end{array}$ & 1 & $0.3 \%$ \\
\hline $\begin{array}{l}\text { Belum } \\
\text { terdaftar }\end{array}$ & 1 & $0.3 \%$ \\
\hline Diluar kota & 1 & $0.3 \%$ \\
\hline $\begin{array}{l}\text { Hak pilih di } \\
\text { luar Surabaya }\end{array}$ & 1 & $0.3 \%$ \\
\hline Ke luar negeri & 1 & $0.3 \%$ \\
\hline $\begin{array}{l}\text { KTP dari luar } \\
\text { pulau }\end{array}$ & 2 & $0.7 \%$ \\
\hline KTP luar kota & 1 & $0.3 \%$ \\
\hline $\begin{array}{l}\text { KTP masih } \\
\text { dalam proses }\end{array}$ & 1 & $0.3 \%$ \\
\hline $\begin{array}{l}\text { Kurang 1 bulan } \\
\text { lagi 17 tahun }\end{array}$ & 1 & $0.3 \%$ \\
\hline $\begin{array}{l}\text { Pindahan dari } \\
\text { luar kota }\end{array}$ & 1 & $0.3 \%$ \\
\hline $\begin{array}{l}\text { Rumit } \\
\text { pemindahan } \\
\text { ke Surabaya }\end{array}$ & 1 & 1 \\
\hline $\begin{array}{l}\text { Sama seperti } \\
\text { sebelumnya }\end{array}$ & 1 & 1 \\
\hline
\end{tabular}

\begin{tabular}{|l|l|l|}
\hline $\begin{array}{l}\text { Sedang di luar } \\
\text { kota }\end{array}$ & 2 & $0.7 \%$ \\
\hline $\begin{array}{l}\text { Tapi hanya } \\
\text { presiden saja } \\
\text { karena } \\
\text { menggunakan } \\
\text { form A5 }\end{array}$ & 1 & $0.3 \%$ \\
\hline $\begin{array}{l}\text { Tidak bisa } \\
\text { mengurus, } \\
\text { ribet karena } \\
\text { anak Solo }\end{array}$ & 1 & $0.3 \%$ \\
\hline $\begin{array}{l}\text { Tidak } \\
\text { mengurus }\end{array}$ & 2 & $0.7 \%$ \\
\hline $\begin{array}{l}\text { Tidak } \\
\text { terdaftar }\end{array}$ & 1 & $0.3 \%$ \\
\hline $\begin{array}{l}\text { TPS beda 2 } \\
\text { gang }\end{array}$ & 1 & $0.3 \%$ \\
\hline Total & 25 & $100 \%$ \\
\hline
\end{tabular}

Sumber : Olahan Data

Data keikutsertaan pemilu yang cenderung tinggi tersebut kongruen dengan pernyataan yang kemukakan KPUD Jawa Timur (Jatim, 2019). Choirul Anam sebagai ketua KPUD Jawa Timur menyebutkan bahwa rata-rata tingkat partisipasi masyarakat Jatim $82.35 \%$ atau jauh di atas target partisipasi masyarakat secara nasional sebesar $77.5 \%$. la juga menyebutkan bahwa dibandingkan dengan Pemilu 2014, tingkat partisipasi masyarakat pada meningkat tajam, yaitu pemilu anggota legislatif meningkat $75.11 \%$ dan pemilu presiden meningkat hingga $70 \%$.

Pada hasil paparan tentang literasi media akan terbagi menjadi 2 bahasan pokok, yaitu literasi media pada ranah kompetensi personal dan kompetensi sosial. Pada ranah kompetensi personal, responden dapat disebut melek teknologi. Temuan ini terlihat pada ranah kompetensi personal, yaitu use skills responden berada pada level medium (2.87). Level yang sama 
juga ditemukan sebagai pada aspek critical skills (2.82).

Level medium pada use skills yang dikuasai responden tercermin dalam variabel technical skills. Variabel ini dibagi lagi menjadi 3 indikator, yaitu (1) kemampuan menggunakan komputer dan internet, (2) kemampuan menggunakan media secara aktif, dan (3) kemahiran menggunakan internet.

Pada kemampuan menggunakan komputer dan internet, hasil menunjukan bahwa responden menguasai kemampuan menggunakan komputer dan internet. Sebanyak $63,9 \%$ responden mengerti cara menggunakan link untuk terhubung dengan laman website lain yang berisi informasi dengan pemilu. Temuan ini didukung dengan sebanyak $67.5 \%$ responden yang mampu menggunakan browser untuk mencari informasi secara mandiri tentang pemilu. Selain itu, 70.5\% responden juga tahu cara menyimpan laman website dan sebanyak $86.1 \%$ mengetahui cara menyimpan bookmark.

Pada indikator kemampuan menggunakan media secara aktif, hasil menunjukan bahwa pencarian latar belakang kandidat dalam pemilu ternyata lebih banyak dilakukan melalui media sosial. Sebanyak $91.8 \%$ responden menggunakan media sosial sebagai medium untuk mencari informasi tentang kandidat dalam pemilu.

Menyusul berada di urutan setelahnya, sebanyak $84.5 \%$ responden menggunakan browser sebagai medium pencarian informasi tentang kandidat dalam pemilu. Kedua temuan ini sejalan dengan temuan yang dipaparkan di awal, yaitu mayoritas responden menjadikan handphone sebagai gadget utama yang dikonsumsi. Pada urutan kedua dan ketiga, responden cenderung menggunakan laptop. Dengan demikian, sumber-sumber online menjadi rujukan informasi utama bagi responden ketika dihadapkan pada kebutuhan informasi tentang Pemilu.

Penggunaan browser sebagai platform kedua yang paling banyak diaskes (setelah media sosial). Temuan tentang browser digunakan untuk mencari informasi kandidat sejalan dengan temuan yang menunjukan bahwa $54 \%$ responden yang mencari informasi tentang kandidat calon anggota DPRD dan DPRD-RI melalui website KPI. Angka yang tidak jauh berbeda juga ada ditemukan pada responden yang mencari informasi tentang kandidat calon presiden melalu website KPI, yaitu 60.6\%. Dapat dipahami bahwa responden juga mempu mencari informasi tentang kandidat dalam Pemilu melalui website KPU.

Temuan lain yang menarik adalah sebanyak $63.9 \%$ responden yang mencari informasi tentang pemilu melalui aplikasi chat.

Jika dibandingkan dengan media sosial dan browser, maka terlihat bahwa chat merupakan sumber yang paling kurang diminati. Namun, jika dibandingkan dengan website KPU, maka terlihat bahwa keduanya tidak memiliki perbedaan yang signifikan. Temuan ini merefleksikan situasi dimana responden masih ada kemungkinan terpapar hoax tentang pemilu. Banyak ditemukan bahwa hoax bersumber dari pertukaran pesan melalui aplikasi chat (Juditha, 2018)

Pada indikator kemahiran menggunakan internet, temuan menunjukan bahwa responden memiliki kemampuan yang tinggi dalam menggunakan internet. Ini dibuktikan dengan adanya $87.7 \%$ responden yang mengetahui cara mengakses informasi tentang Pemilu lewat intenet dengan menggunakan berbagai gadget. 
Temuan di atas menunjukan bahwa secara teknis, responden memiliki kemampuan mencari informasi tentang pemilu. Hasil ini kongruen dengan preferensi gadget responden, yaitu handphone dan komputer (desktop atau laptop). Bila dilihat dari rentang usia responden, temuan ini merefleksikan sebuah realita bahwa generasi muda memang akrab dengan penggunaan gadget [SUMBER].

Selanjutnya, pada level critical understanding yang tercermin dalam variabel cognitive skills.

Variabel ini terbagi dalam 3 indikator, yaitu (1) kemampuan memahami konten dan fungsi media; (2) pengetahuan tentang media dan regulasi media; dan (3) perilaku pengguna internet dalam menggunakan media.

Pada indikator pemahaman konten dan fungsi media, ditemukan bahwa $72.5 \%$ responden mengakui bahwa mereka menyukai informasi politik dan pemilu yang disajikan media. Kendati menyukai informasi tentang politik dan pemilu, responden tidak asal mempercayai informasi tersebut. Responden melakukan prosedur verifikasi untuk memmbuktikan kebenaran tersebut. Sebanyak 77.5\% responden melakukan verifikasi terhadap informasi politik dan pemilu yang dikonsumsi.

Terkait verfikasi ini, sebanyak $73.7 \%$ responden membutuhkan data statistik sebagai bahan verifikasi. Ini menunjukan bahwa responden telah menyadari pentingnya data kuantitatif sebagai pendukung sebuah informasi. Namun, data dalam verifikasi berita. Belakangan ini banyak ditemukan lembaga survei yang tidak independen; mereka merilis data statistik yang sesuai kepentingan klien yang menggunakan jasa mereka. Dalam menghadapi hal ini, sebanyak 69.5\% responden berusaha mencari tahu latar belakang lembaga survei yang memuat informasi tentang pemilu.

Selain berusaha memverifikasi, responden juga secara jeli berusaha membedakan judul-judul artikel yang termasuk hoax. Sebanyak $82.1 \%$ responden mengaku bisa membedakan judul-judul artikel yang termasuk hoax dan bukan. Dengan semakin banyaknya media yang membuat informasi tentang politik dan pemilu, maka respon mereasa semakin rentan terpapar hoax pemilu. Oleh karena itu mereka menentukan media mana saja yang mereka anggap kredibel dan bisa dipercaya (85.1\%). Cara mereka menentukan media yang dapat dipercaya adalah dengan memperhatikan latar belakang media yang membuat berita tentang pemilu (85.1\%). Namun, ini tentu tidak mudah dilakukan sebab media semakin partisan dalam pemberitaannya tentang politik dan pemilu

Pada indikator kedua, yaitu pengetahuan tentang media dan regulasi media, ditemukan bahwa $67.5 \%$ responden mengetahui tentang UU ITE yang meregulasi tentang praktik media. Mereka juga mengetahui bahwa ada sanksi hukum bagi pengguna internet yang menyebarkan/membuat hoax. Sebanyak $83.8 \%$ responden mengetahui tentang sanksi dari UU ITE ini.

Pada indikator selanjutnya, yaitu Perilaku pengguna internet dalam menggunakan media, ditemukan bahwa perilaku responden lebih didominasi 
dengan perilaku menyebarkan informasi tentang pemilu.

Sebanyak $52.6 \%$ responden mengaku selalu membagikan informasi tentang pemilu yang didapat. Selain itu, responden juga mengetahui bahwa ada banyak perilaku-perilaku lain di internet terkait konten pemilu. Sebanyak $99.3 \%$ responden tahu bahwa ada pengguna internet yang menyebarkan hoax. Sebanyak 91.5\% responden juga tahu bahwa ada pengguna internet yang berusaha meluruskan hoax tersebut. Selain tentang sirkulasi hoax, 90.4\% responden juga mengetahui bahwa informasi pemilu dibuat menjadi konten humor di internet.

Selain individual competence, ranah social competence juga tercakup dalam penelitian ini. Ranah social competence ini membahas tentang tingkat communicative abilities responden. Ada 2 indikator yang diujikan dalam communicative competence, yaitu (1) kemampuan untuk berpartisipasi dengan masyarakat melalui media dan (2) Kemampuan untuk memproduksi dan mengkreasi konten media. Pada ranah social competence, responden dapat disebut melek teknologi. Hal ini tercermin pada hasil yang ditemukan melalui kedua indikator yang digunakan.

Pada indikator pertama, yaitu kemampuan untuk berpartisipasi dengan masyarakat melalui media, hasil menunjukan bahwa terkait communicative abilities, responden cenderung tidak berpartisipasi dalam tautan tentang pemilu.

Terbukti bahwa hanya ada 28.8\% responden yang menyatakan bahwa mereka selalu menuliskan komentar di tautan tentang pemilu. Selain itu, hanya ada $25.9 \%$ responden yang menduplikasi konten dan/atau menambahkan tajuk dari konten yang diduplikasi tersebut. Namun, jika responden merasa bahwa ada kekeliruan dalam tautan tentang pemilu dan responden memiliki data yang benar, maka barulah mereka berpartisipasi. Sebanyak $64.9 \%$ responden mengaku berpartisipasi dengan berkomentar atau memberikan data pembanding ketika terdapat berita yang tidak benar.

Pada indikator kedua, hasil menunjukan bahwa meskipun responden menyukai konten-konten pemilu, namun partisipasi responden dalam membuat konten pemilu ternyata masih rendah. Hanya ada $16.5 \%$ responden menulis artikel tentang pemilu. Dalam bentuk visual/audio visual pun hanya ada $14.2 \%$ responden yang membuatnya. Data ini kongeruen dengan bentuk partisipasi responden dalam bentuk komentar. Dapat dipahami bahwa pada poin partisipasi, hanya ada sebagia kecil responden yang bersedia untuk mengikuti. Latar belakang pendidikan dapat disebut sebagai salah satu faktor pendukung tingkat literasi seseorang

\section{Kesimpulan}

Tingkat literasi media pemilih pemula sudah berada pada level medium, baik pada ranah kompetensi personal dan kompetensi sosial. Untuk keterampilan sifatnya teknis (technical skill), pemilih pemula cenderung tidak memiliki kesulitan ketika dihadapkan pada gadget. Mereka mengetahui secara teknis mencari, membuat, hingga membagikan, memblokir informasi tentang pemilu. Bahkan responden juga cenderung tidak menelan bulat-bulat informasi yang diterima secara online (memiliki critical understanding) Terbukti dengan 
kemampuan pemilih pemula dalam memverifikasi informasi pemilu yang dikonsumsi. Mereka juga mengetahui tentang keberadaan hoax dan media yang partisan. Kendati demikian, pemilih pemula tidak tertarik untuk berpartisipasi dalam menciptakan konten-konten baru (tahap communicative abilities) tentang pemilu.

Pemilih pemula menyadari bahwa media sosial memiliki fitur komentar, namun tidak mereka gunakan untuk untuk berdiskusi tentang isu pemilu. Mereka juga enggan untuk menduplikasi dan menambahkan tajuk di tautan tentang politik melalui media sosialnya. Keengganan ini juga terjadi ketika mereka melihat adanya perdebatan tentang hoax politik. Pemilih pemula siaga terhadap peredaran hoax, namun cenderung enggan untuk meluruskan pendapat orang-orang yang sudah terpapar dengan hoax.

Keengganan berpartisipasi membuat konten media tentang pemilu ini bukan berarti responden pemula tidak mampu membuat konten. Jika dilihat dari tingkat pendidikannya, maka tampak bahwa pemilih pemula termasuk golongan orangorang yang sebenarnya mampu menyampaikan pendapat. Kurang tertariknya pemilih pemula ini sebenarnya dapat dilihat dari topik informasi yang paling mereka minati. Gaya hidup dan pendidikan merupakan 2 topik utama yang disukai. Dengan kata lain, topik tentang politik dan pemerintahan tidak diminati oleh pemilih pemula. Dengan demikian, wajar ketika pemilih pemula tidak berpartisipasi membuat konten tentang topik politik yang tidak disukainya.

\section{Referensi}

Astrika, L., \& Yuwanto, Y. (2019). Ujaran Kebencian dan Hoaks: Signifikasinya terhadap Pemilih Pemula di Kota Semarang. Jurnal Ilmiah Ilmu Pemerintahan, 4(2), 107. Jurnal KOMUNIKATIF Vol. 10 No. 1 Juli 2021 https://doi.org/10.14710/jiip.v4i2.5433

Celot, P., \& Pérez Tornero, J. M. (2009).

Study on Assessment Criteria for

Media Literacy Levels: A

comprehensive view of the concept

of media literacy and an

understanding of how media literacy

levels in Europe should be assessed.

European Association for Viewers'

Interests, October, 1-92.

Centre for Media Literacy. (2008).

MediaLitKit: Literacy for the 21st

century. In Literacy.

Hamna, D. (2017). Eksistensi Jurnalisme Di

Era Media Sosial. Jurnal Jurnalisa, 3(1), 106-120.

https://doi.org/10.24252/jurnalisa.v3i

1.3090

Hidayat, Dadang Rahmat ;Basith, A.

A. ;Muhamad Z. A. F. (2019).

LITERASI MEDIA SOSIAL UNTUK

PEMILIH PEMULA.

Huvila, I. (2012). Information services and digital literacy. In Information Services and Digital Literacy.

https://doi.org/10.1016/b978-1-

84334-683-8.50003-3

Iriantara., Y. (2009). Literasi Media.

Simbiosa Rekatama Media.

Jatim, K. (2019). KPU Jatim Sebut

Partisipasi Masyarakat Capai 82,5

Persen Di Pemilu 2019.

http://kominfo.jatimprov.go.id/read/

pilkada-jawa-timur/kpu-jatim-sebut-

partisipasi-masyarakat-capai-82-5-

persen-di-pemilu-2019

John, Cook;Lewandowsky, S. (2005). The

Debunking Handbook.

Juditha, C. (2018). Hoax Communication

Interactivity in Social Media and

Anticipation (Interaksi Komunikasi

Hoax di Media Sosial serta

Antisipasinya). Journal Pekommas,

3(1), 31.

https://doi.org/10.30818/jpkm.2018.2

030104

Juliswara, V. (2017). Mengembangkan 
Model Literasi Media yang

Berkebhinnekaan dalam

Menganalisis Informasi Berita Palsu

(Hoax) di Media Sosial. Jurnal

Pemikiran Sosiologi, 4(2), 142.

https://doi.org/10.22146/jps.v4i2.285

86

Mass communication. (1994). In

Communication Booknotes (Vol. 25,

Issue 5). Mc Graw Hill.

https://doi.org/10.1080/10948009409

389738

Novia, R., \& Mustika, M. (2019). RespoN

Pemilih Muda Surabaya terhadap

berita hoaks di media sosial terkait

pemilihan Presiden Indoneia.

Katadata, 07, 496-510.

https://databoks.katadata.co.id/data

publish/2019/05/16/pengguna-

internet-di-indonesia-2018-

bertambah-28-

juta\%oAhttps://databoks.katadata.c

o.id/datapublish

Paskarina, C., \& Rina;Nuraeni. (2017).

EDUKASI ANTI-HOAXDALAM

PEMILU MELALUI METODE

DEBUNKING. Jurnal Articel, 1-4.

Potter, W. J. (n.d.). Theory of Media Literay.

SAGE Publications Inc.

Rianto, P. (2019). Literasi Digital Dan Etika

Media Sosial Di Era Post-Truth.

Interaksi: Jurnal Ilmu Komunikasi,

8(2), 24.

https://doi.org/10.14710/interaksi.8.2.

24-35

Sosiawan, E. A., \& Wibowo, R. (2020).

Kontestasi Berita Hoax Pemilu

Presiden Tahun 2019 di Media Daring

dan Media Sosial. Jurnal Ilmu

Komunikasi, 17(2), 133.

https://doi.org/10.31315/jik.v17i2.369

5

Susman-peña, T., Druckman, M., \& Oduro,

N. (2020). Fighting Misinformation:

Digital Media Literacy. 80.

Tacchini, E., Ballarin, G., della Vedova, M.
Some like it hoax: Automated fake news detection in social networks.

ArXiv, 31(2), 211-236. 